Sabine Kienitz, Michael Friedrich, Christian Brockmann \& Alessandro Bausi (éd.), Manuscripts and Archives:

Comparative Views on Record-Keeping, Berlin-Boston 2018, p. 171-200

Jean-Luc Fournet

\title{
Archives and Libraries in Greco-Roman Egypt
}

\begin{abstract}
Owing to the mass of its documentation, Egypt gives many examples of discoveries of documentary and literary papyri. The papyrologists traditionally speak of 'archives' for documentary texts and 'libraries' for literary texts, a polarity which reflects the two fundamental branches of papyrology, namely documentary papyrology and literary papyrology. But is it epistemologically correct? Does this reflect reality? The situation is actually less clear: many ancient sets combined both documents and books. After presenting the archives and the libraries as evidenced by papyri, I will try to show examples of these combinations and expose the reasons that make them so difficult to detect, to the detriment of papyrology and of our understanding of ancient culture in general.
\end{abstract}

\section{Introduction}

'Archives' and 'libraries' are two terms used by papyrologists to designate collections of either documentary or literary texts (henceforth 'documents' and 'books' respectively). As far as classical Antiquity is concerned, archives and libraries are best known from allusions made to them in literary sources. And, with a few exceptions (including the famous case of Herculaneum), Greco-Roman Egypt is the only place where climatic conditions allowed for the massive preservation of documents and books which constituted ancient archives and libraries. But the conditions in which they were discovered in the nineteenth and twentieth century unfortunately did not permit these ancient collections to come down to us in their entirety.

The interest in these ancient collections, which has developed particularly in recent decades, is doubly justified:

(a) Apart from the content of the texts they are composed of (which are the delight of historians and philologists), these collections are archaeological objects that form a whole and that we need to reconstruct and study as such. They tell us about the ways of keeping and filing written texts practiced by the ancients. In other

I thank Adam Bülow Jacobsen and Korshi Dosoo for revising my English and Antonio Ricciardetto for proof-reading my paper.

https://doi.org/10.1515/9783110541397-006, (c) BY-NC-ND (C) 2018 J.-L. Fournet, published by De Gruyter. This work is licensed under the Creative Commons Attribution-NonCommercial-NoDerivs 3.0 License. 
words, the information they give us is a matter of library studies, archival studies and the history of knowledge;

(b) We must analyse documents or books, not only in themselves, but in relation to the way they were organized. The relationship between the components of a collection is meaningful and provides new data in addition to those provided by each of the components; more precisely, it strengthens, enlivens and puts into perspective such information. As Orsolina Montevecchi wrote about archives,

l'archivio, e specialmente un archivio privato che si estenda per un certo lasso di tempo, è un insieme più vivo e istruttivo, per certi aspetti, di una serie di documenti omogenei, i quali ci possono dare in modo impersonale l'evoluzione di un determinato istituto giuridico nella sua prassi. L'archivio ci permette una specie di sondaggio in un settore del mondo antico, a scala reale: lo studio di un campione, che può essere una famiglia per due generazioni, con tutte le sue vicende di nascite, morti, matrimoni, relazioni di lavoro e di affari, rapporti con le autorità, ecc. Oppure l'estensione cronologica può essere minore ma più ampia la cerchia in senso orizzontale: relazioni d'interessi, questioni giudiziarie, affinità sprirituali o religiose, ecc. ${ }^{1}$

This applies even to books which constitute libraries. When put back in the context of the collections to which they once belonged, documents or books are put back in the context of their drafters or readers; they illuminate and complement one another so as to uncover historical, institutional, cultural facts, which are not the result of the 'cobbling-together' which we are often obliged to practise, bringing together data originating from various communities, places and periods. Thus, reconstructing archives and libraries is not merely an enjoyable jigsaw puzzle, it is a real tool for analysing ancient texts.

It is only fairly recently that we have begun to realize the importance of archives. The first generations of papyrologists paid more attention to unique and exceptional documents, without taking into account the groups to which they belonged; they also organized their discipline by dividing these texts into meaningful categories (such as the various documentary genres). As outstanding texts became scarcer, and as discoveries of important archives (for instance, that of the katochoi of the Serapeum or that of Dioscorus of Aphrodite, masterfully edited respectively by Ulrich Wilcken ${ }^{2}$ and Jean Maspero ${ }^{3}$ ) began to show how interesting the archival method could be, they began to pay more attention to the ancient groups of texts, and the reconstruction of these groups little by little took precedence over the study of individual texts.

1 Montevecchi 1988, 247.

2 UPZ I 2-105.

3 P.Cair.Masp. I-III. 
The so-called 'museum archeology' method ${ }^{4}$ was developed and theorized these last decades: it aims at reconstructing antique archives dismembered when they were illegally discovered, by trying to trace the history of purchases by European or American collections through a police-like investigation conducted in the inventory registers.

For instance, if one and the same archive has been split up or if one and the same papyrus has been torn to pieces and if those papyri or fragments have turned up in different collections, there must be a link between the acquisitions of the collections in question. ${ }^{5}$

In the case of discoveries made during authorized excavations, one began to take better account of the archaeological data: in a seminal article, Peter van Minnen demonstrated how fruitful the method of the 'house-to-house enquiry' is for the village of Karanis excavated by the Americans, using the old excavations reports and taking into account all the material found in these houses, so that he could individuate the house and the archive of the tax-collector Socrates. ${ }^{6}$ In 1989 the papyrologists Jean Bingen and Willy Clarysse decided-for the first time to my knowledgeto publish the ostraca found in the Belgian excavations in Elkab (Upper Egypt) not by documentary types (as it was usual), but by finding areas, i.e. by houses they were discovered in: thus they were able to reconstruct archives owned by the inhabitants of these houses. ${ }^{7}$ Finally, I must not forget a book that gave, so to speak, its pedigree to the archival method: A Guide to the Zenon Archive by P.W. Pestman in $1981 .^{8}$ So today we publish new papyri only after trying to reconstruct the archives they come from. The development of this interest in archives can be read in the following figures:

- in 1973, Montevecchi in the first edition of her handbook La papirologia made a census of 96 archives;

- $\quad$ in her second edition (1988), she added 39 more, bringing the total to 135;

- in 2014, the online database devoted to Archives on the Trismegistos website registers 482 archives. $^{9}$

4 See Vandorpe 1994.

5 Vandorpe 2009, 228-229.

6 Van Minnen 1994.

7 O.Elkab.

8 Pestman/Clarysse/Korver/Muszynski/Schutgens/Tait/Winnicki 1981.

9 Papyrus Archives in Graeco-Roman Egypt (http://www.trismegistos.org/arch/index.php). References to the archives as registered in this database will be made with \# followed by a number. The figure I have just given includes groups of texts that are not actual archives, but libraries 
It is true that it includes archives that are not only in Greek but also in Demotic or Coptic (since papyrology in recent years has become interdisciplinary). But as a matter of fact, this exponential growth is the result of a deep trend.

If, in this introduction, I have mostly considered archives, that is because there has been much less interest in libraries. The archival method has more rarely been applied to libraries, for reasons related not only to the difficulty of tracing the books that made up antique libraries now scattered into several collections, but above all because of the state of mind of literary papyrologists who were more interested in the content of the texts than in their context. It is symptomatic that Orsolina Montevecchi, in her handbook, did not devote a single line to libraries while she dedicated a chapter to archives. Fortunately, this has been changing in recent years, especially through the study of some famous ensembles such as the so-called 'Bodmer Library'. ${ }^{10}$

After this long introduction setting out the methodological framework, I will review the two types of sets (archives and libraries), such as documented by the Egyptian papyri and the epistemological reflections which papyrologists have been led to by studying them. But I would also question the distinction we draw between archives and libraries by analysing, in the last part, cases where archives and libraries are mixed and the lessons we can draw from this combination.

\section{Archives}

\subsection{Problems of definition}

The term 'archive' encompasses many realities and there has not always been a general agreement on the meaning and use of this word. ${ }^{11}$

\subsubsection{Public and private archives}

The first distinction that was made between public archives-containing official documents produced by the administration and/or private documents registered

(17), not to mention the mixed ensembles of the recluses of the Serapeum (\# 72) and of Dioscorus of Aphrodite (\# 119). See below.

10 See recently the conference I papiri Bodmer: Biblioteche, comunità di asceti e cultura letteraria in greco e copto nell'Egitto tardoantico, Rome, Università La Sapienza, 3 February 2014 (the proceedings are now published in Adamantius 21 [2015]). See below.

11 See Pestman 1989; Martin 1994; Jördens 2001; Van Beek 2007; Vandorpe 2009. 
and kept by the administration-and private archives, i.e. documents accumulated by an individual, a family or a community of individuals. In papyri, only the first of these receive a designation, i.e. a generic one as $\alpha \rho \chi \varepsilon \tilde{o v}$, or a more specific one

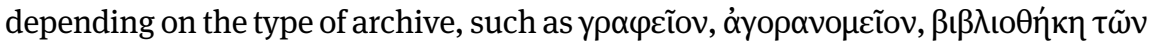

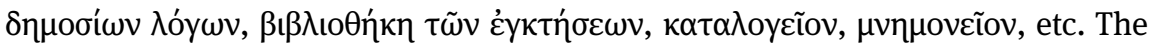
latter ones are never identified by name. People speak of their papers ( $\chi \alpha \rho \tau \alpha i)$, their

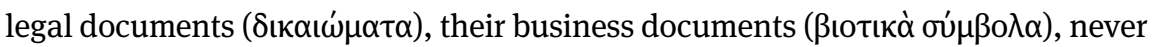
of their 'archives' as a whole. ${ }^{12}$

\section{See for example P.Cair.Masp. II 67167, 33-38 (566-573 CE):}

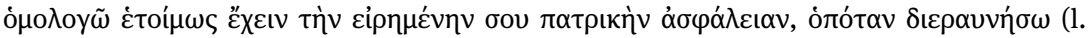

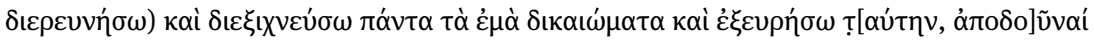

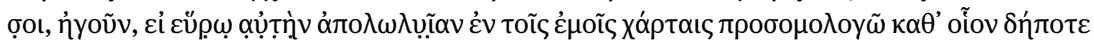

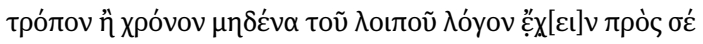

I declare that I am ready to give you back the document (= acknowledgement of debt) signed by my father when I have searched, identified and found it in all my business documents and, if I see that it is lost in my papers, then I also declare that in any way and at any time I will not be holding you any more to account for anything. ${ }^{13}$

Some historians and papyrologists have argued that only public records should be called 'archives' ${ }^{14}$ and denied that denomination to private archives. ${ }^{15}$ But this position is now very much a minority.

The German papyrologist Andrea Jördens, following the terminology developed by Eckhart G. Franz in his Einführung in die Archivkunde, proposed to use, for private archives, the term Nachlass 'succession, inheritance', which is actually more accurate in that it insists on the fact that private archives are collections of documents left by people after their death. ${ }^{16}$

12 P.Tebt. I 52 (114 BCE).

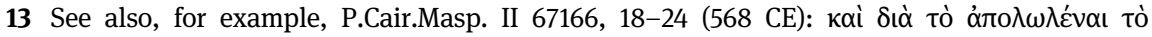

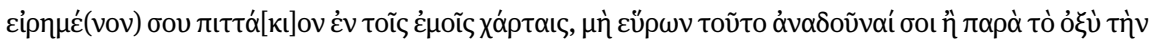

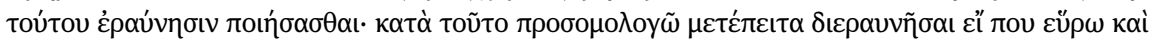

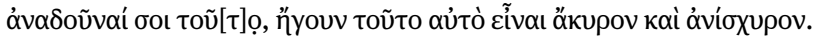

14 See Mélèze-Modrzejewski 1979, 120: ‘[...] les vraies [archives], c'est-à-dire les dépôts publics de documents, et non pas ce qu'on appelle archives dans le jargon papyrologique'.

15 See Moses I. Finley, quoted by Mélèze-Modrzejewski 1989, 559-560 in a new critique of the usage of the word 'archives' by papyrologists. One might note his constant use of inverted commas ('guillemets' in the French print, « archives ») around the word.

16 Jördens 2001, 261. Franz 1993 defines 'Nachlass' as 'die nachgelassene private Registratur einer Persönlichkeit.' He distinguishes between 'echter Nachlaß’ ('der tatsächlich aus der Tätig- 


\subsection{2 'Archive'}

The use of the word 'archive' for collections of a private nature is nonetheless legitimate. However, we need first to agree on what it means. Not every group of papyri is necessarily an archive. The criteria that justify the term 'archive' has been the subject of much debate in recent years.

The first criterion, the most objective, is the fact that the papyri were found together. But it is far from enough. For example, Achille Vogliano discovered, in 1934, in the village of Tebtynis a collection of 750 texts (including Callimachus' Diegeseis) in the cellar of a house, now known as the 'cantina dei Papiri'. But they are actually discarded papyri from various origins and various archives (at least three: Patron's descendants [\# 66], Kronion son of Cheos [\# 125] and Pakebkis' descendants [\# 64]). ${ }^{17}$

Pieter W. Pestman added another decisive criterion: archives are documents 'which in Antiquity had been brought together, for some precise purpose'. ${ }^{18}$ Alain Martin in turn refined this definition: 'elles doivent, dès l'Antiquité, avoir fait l'objet d'une accumulation et d'un classement délibéré'. ${ }^{19}$ Otherwise, we are dealing with a dossier, not an archive. If the criterion of accumulation is objective, that of classification is more subjective and difficult to distinguish a posteriori, especially after the disturbances suffered by the sets before reaching the collections or even before being discovered by archaeologists. However, we may cite some examples of discoveries of archives, classified or arranged as such when they were abandoned or hidden. For instance, the archive of the Narmouthis temple discovered in 1937 by Achille Vogliano:

Un nucleo di questi ostraca era disposto in due grossi recipienti d'argilla e si aveva l'impressione che la loro collocazione-adagiati com'erano l'uno sull'altro-rispondesse ad un vero e proprio ordinamento. ${ }^{20}$

\footnotetext{
keit einer bestimmten Person erwachsen ist und als provenienzmäßig geschlossener Fonds erhalten bleibt'), 'angereicherter Nachlaß' ('der durch eigene Briefe des Nachlassers, einzelne Autographen und Materialien über ihn vervollständigt ist') and 'unechter Nachlaß’ ('der ohne echten Kern nachträglich als Sammlung von Briefen, Manuskripten und Sekundärmaterial über eine Person zusammengetragen worden ist').

17 See Gallazzi 1989, 1990.

18 Pestman 1990, 51.

19 Martin 1994, 570: 'They must be the result of a deliberate accumulation and classification since ancient times'.
}

20 Vogliano 1938, 543. 
Moreover, the ostraca have numbers that correspond to a filing order. ${ }^{21}$

Claude Orrieux added a third criterion: an archive must have been the result of a process of selection:

'Real' archives are identified by two objective criteria: first, they have a natural growth in that they are the spontaneous result of individual or collective activity which gives birth to them and is reflected in them; secondly, they are subject to a partial discrimination, namely between pieces to keep or to destroy, depending on their future use. ${ }^{22}$

But, as noted by Alain Martin, the criterion of partial discrimination is difficult to prove. ${ }^{23}$ In addition, the archives that have survived are themselves discarded material, that is to say sets of pieces that at some point someone decided not to keep, but to discard. In other words, they are 'negative' or 'hollow' archives.

Alain Martin finally distinguishes a special type of archive: the documentary cache ('cachette documentaire'). ${ }^{24}$ It is a group of documents intentionally buried by their owners and being the result of a more drastic selection due to exceptional circumstances (war, rebellion, persecution). They differ from the archives found in situ or those discarded.

\subsubsection{Location of archives}

We can see that the places of discovery of archival collections are crucial to define their profile.

(a) A few have been found in their original location after being suddenly abandoned or destroyed. This is the case of the Thmuis or Bubastos public archives, found carbonized (but legible) after a fire. They are archives that were still being used when they were burned.

(b) Others consist of documents that were still useful but that were hidden at some point. These are archives temporarily out of use but intended to be used again. This is probably the case of the still unpublished archive of Karanis (\# 251)

21 See O.Narm.Dem. II, l-li.

22 Orrieux 1985, 41, my translation (see the original French, 'De "vraies” archives se reconnaissent à deux critères objectifs: d'une part elles ont une croissance naturelle, en ce sens qu'elles résultent spontanément de l'activité individuelle ou collective qui leur donne naissance et s'y reflète; d'autre part, elles font l'objet d'une discrimination partielle, à savoir entre les pièces à conserver ou à détruire, en fonction de leur utilisation future').

23 Martin 1994, 572.

24 Martin 1994, 575. 
'found in a hollow threshold of a door in the 1920,' and certainly of the two archives found in the 'cave of letters' in the Nahal Hever in the Judean Desert where refugees of the Bar Kokhba revolt (132 CE) took shelter. Among them there was a certain Babatha who buried 35 documents having previously taken care to classify them into bundles wrapped in linen and tied with a string, put into a leather pouch, itself put into a water skin (\# 41). ${ }^{25}$ The care taken by Babatha to pack these texts shows that she wanted to recover them, once peace would be restored, to assert her rights to certain properties.

(c) Most archives were discarded in secondary areas of the house: in the basement or cellars (see the Milon archive [\# 141] ${ }^{26}$ ), behind a staircase, or in a tomb (see the archive of the embalmers or choachytai $[\# 50]^{27}$ ). They are collections that people wanted to keep even if they had become obsolete. Most of the time one or more ceramic containers were used: among these is the Totoes archive, from the second century BCE (\# 248), placed in two jars and that of Papas, from the seventh century CE (\# 170) (Fig. 1). Care was taken to protect documents, even if they were out of use, so that they would not shatter, by wrapping them in bundles with a piece of cloth (see archive of Teos, fourth century BCE [\# 228] $]^{28}$ ) or by protecting them with reeds to prevent the rolls from being broken (see the Melitian archive from Labla, 511-513 [\# 83]). ${ }^{29}$ Bundles often demonstrate a clear arrangement, and this arrangement explains the fact that batches of papyri which are held in different collections, but which originally came from larger illegally discovered archives (such as Zeno's [\# 256]) often show an internal coherence corresponding to the original bundles.

25 Yadin 1962, 231-232: 'In one of [a water-skin], a large collection of balls of flax thread and a well packed parcel were found. The outer wrapping of the parcel consisted of a sack, carefully fastened with a twisted rope; inside there was a leather case with many papyri packed tightly together. When the parcel was opened, it was found to contain the archive of Babata daughter of Simeon. [...] Under the skins was found an elegant leather purse, with a rosette design on each of its sides. The purse was torn and the batch of documents it had contained had apparently slipped out of it onto the sloping bottom of the crevice. This batch included a leather scroll fastened with thread; a papyrus deed placed in a reed container; and five rolled papyri.'

26 P.Eleph., 34.

27 See P.Choach.Survey, 10-13.

28 See the picture in Vandorpe 2009, 220-221.

29 Flinders Petrie, quoted by McGing 1990, 67: 'Each [deed] was rolled up separately; the rolls were then bound round, along with slips of reed, to prevent their being bent or broken; then tied up in a linen cloth; next in a large lump of old tattered woollen embroidery; and the bundle placed in a big jar sunk in the ground'. 


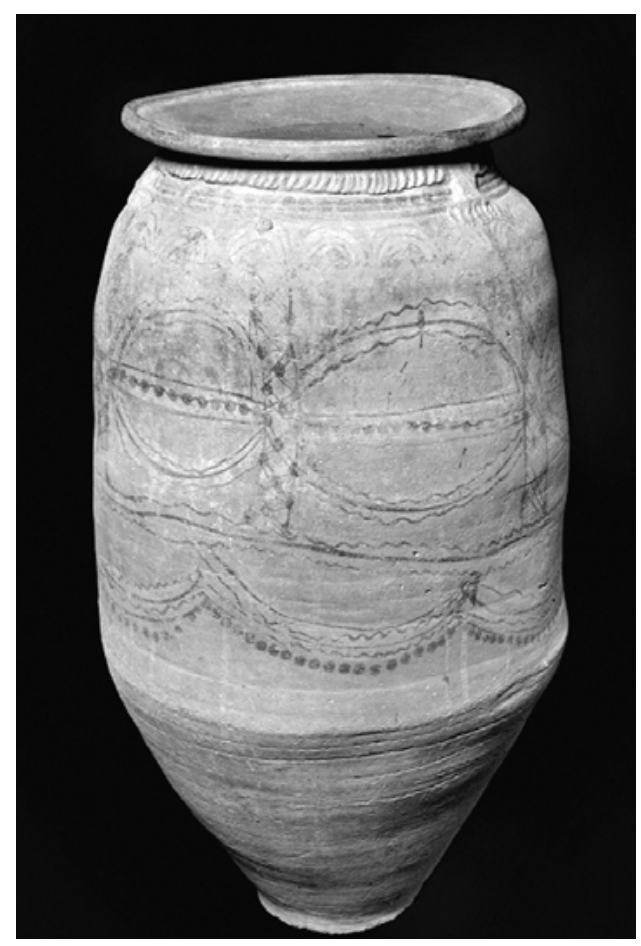

Fig. 1: The jar in which the Archive of Papas was discovered. (C IFAO.

(d) Obsolete archives might also be simply discarded: they ended up in garbage dumps (public or private), more or less scattered or mixed. The way they were excavated did not help matters: in the past, dumps were often excavated without respecting their stratigraphy: 'one attacked the mound laterally, caused slices of it to fall one by one, and sorted out the papyri after each "landslide", instead of 'removing the layers separately, which demands a high degree of concentration when they cross over or under each other'. ${ }^{30}$ When excavating dumps in the Eastern Desert fortresses, we were able to distinguish mini-archives of ostraca corresponding to the contents of the basket with which the soldier discarded documents which had accumulated in his room when he wanted to clean it. $^{31}$

30 Cuvigny 2009, 53.

31 See J.-P. Brun in Cuvigny (ed.) 2006, 63-67. 
(e) Obsolete archives could be also recycled. The scrolls they were composed of, normally only written on the front side, could serve as second-hand paper: their back could be used for copying other documents. This was the case with two rolls from the archive of the strategos of the Panopolite nome (written in 298 and $300 \mathrm{CE}$ ), which were reused by an individual, Besas Alopex Antoninus, after being stuck together (one written face against the other), and then cut into sheets to make a codex (P.Panop.Beatty). Papyrus could also be reused for other purposes: for mummy cartonnage (masks, foot cases, pectorals, or leg guards made with papyrus and covered with stucco before being painted), or for wrapping and stuffing mummified crocodiles such as those discovered by Grenfell and Hunt in 1900 at Tebtynis, or in 1901 at Talit. ${ }^{32}$ After dismantling cartonnage and opening mummies, papyri sometimes forming archives were discovered, especially administrative archives since the bureaucratic process obliged offices to discard their papers regularly. Some archives (such as that of Adamas, head of the public granary, 199-196 BCE [\# 2]) were scattered among several crocodiles. Unfortunately, information about the provenance of the papyri extracted from crocodile mummies was not recorded by the excavators.

\subsubsection{Common characteristics of archives}

All this shows that the term 'archive' encompasses a variety of archaeological realities corresponding to collections of a different nature. Most papyrological archives, however, have several common characteristics that must be carefully considered by the historians who exploit them:

(a) They are out-of-date, dead. With the rare exception of those which were found in situ, fossilized by an incident like a fire, archives are actually sets of documents that were deemed unnecessary at some point and that were discarded, while relevant documents continued to be used and therefore retained. ${ }^{33}$ As I have already noted, they are 'negative' or 'hollow' archives, and the principles of selection and organization they underwent, which are inherent in the concept of archive, are almost always disturbed by losses and subtractions.

(b) They are partial: either, as we have seen, because of the choices made by heirs or successors, or because of the choices made by the owner who, under the

32 See http://www.papyrology.ox.ac.uk/POxy/VExhibition/images/c7.jpg. (last accessed on 27/02/2017).

33 Nevertheless, the fact that they were often discarded in a part of the house (such as the cellar) shows that they could continue to have some historical or sentimental value. 
constraints of particular circumstances, may have wanted to keep the part of his archive he considered most useful (thus Babatha hid the documents which were strictly necessary); or because of accidents which occurred during their discarding, recycling and conservation. Whatever their size (the smallest contains two papyrus found bound together, ${ }^{34}$ and the largest, the Zenon archive [\# 256], has nearly 2,000 papyri), these archives are fundamentally incomplete. Still worse, with the exception of archives discovered in a scientific excavation, one is never sure, when working on an archive, that it has been discovered in its entirety, given that it could have been scattered all over the world. When trying to reconstruct it, we may deal only with a subset, a dossier. That is why the list of papyrological archives is full of dossiers, and not actual archives.

Problems of definition and methods are more serious than they seem to be due to the fact that archives rarely came down to us in full; these problems affect the way we reconstruct and analyse these sets. It is time to try to sketch a typology of the archives from Greco-Roman Egypt-I shall be brief because this typology is in no way specific to Egypt.

\subsection{Typology}

Three types of archives can be distinguished:

\subsubsection{Official or state archives ${ }^{35}$}

These represent less than a quarter of the known archives. ${ }^{36}$ But this figure is misleading. We have in fact only very few examples of real official record offices: for example, the Bibliotheke of Thmouis (\# 43) or the central archive of the Boubastite nome (\# 22), both destroyed by fire that has virtually 'fossilized' them. Most of the time we are dealing either with discarded texts (mummy-cartonnages) or texts taken by officials when they left their offices, and found in their houses, often mingled with their personal papers. In other words, we do not know much about official archives, except their organization, which may be reconstructed from documentary

34 P.Mich. VIII 490-491 (\# abest).

35 See in general Cockle 1984 and Burkhalter 1990.

36127 entries in the Papyrus Archives in Graeco-Roman Egypt database, among which 117 are exclusively 'official'. 


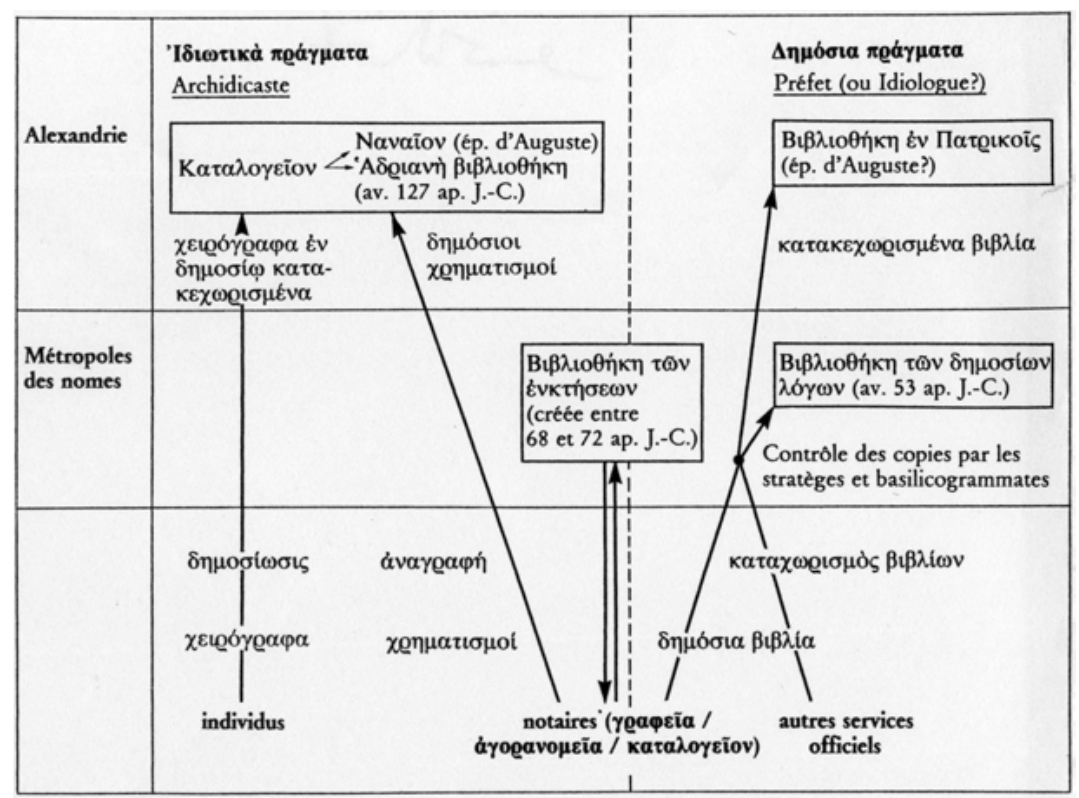

Fig. 2: Local and central archives in Roman Egypt after Burkhalter 1990, 216.

sources (Fig. 2). In fact we know them mainly through 'privatized' samples, documenting the various levels of local administrations-one must keep in mind that weather conditions did not allow the preservation of papyri in Alexandria, the capital of Egypt. ${ }^{37}$

\subsubsection{Private archives}

In theory, we should differentiate between:

(a) personal archives, consisting of papers of an individual;

(b) family archives, consisting of contemporary documents belonging to various members of the same family and collected by the head of the family, but also created diachronically by the accumulation of papers over several generations.

The best example is perhaps the archive of the Apions, an important aristocratic family (\# 15) we can follow from Strategios I in 436 down to Apion III in $619 / 620 .^{38}$

37 On the special case of the tomoi synkollêsimoi, see Clarysse 2003.

38 See Gascou 2008, 183-195 for the Apion family; Mazza 2001; Hickey 2012. 
(c) professional archive (business or book-keeping archive) made up of documents related to the owner's profession.

Generally, these three types of archives are mixed. The best example is the Zenon archive (\# 256) that contains business papers collected by Zenon while he was a representative of the dioikêtês (= minister of finance) Apollonios in Palestine (Phase I, 261-258), a secretary of Apollonios in the Delta (Phase II, 258-256) and a manager of Apollonios' estate in the Fayyum (Phase III, 256-247), as well as all of the private papers written during these three phases and when he retired in Philadelphia as a private citizen (Phase IV, 248/247-229). ${ }^{39}$

\subsubsection{Community archives}

Community archives include archives of professional and cult associations, temples, church, monasteries. They are half-way between official and private archives.

\section{Libraries}

Libraries, public or private collections of literary texts, raise other problems. The most important of these are of a heuristic nature. ${ }^{40}$

\subsection{Tracing libraries}

In comparison to archives, the number of libraries discovered in Egypt is difficult to assess. The Papyrus Archives database of Trismegistos lists 17 libraries plus 2 libraries combined with archives (4\%), against 463 purely documentary archives (96\%). Even if this database does not intend to be exhaustive for libraries, the numerical disproportion between libraries and archives is striking. This is a wellknown phenomenon as far as papyrology in general is concerned: among the nearly 70,000 edited papyri, only 9,000 are literary texts ${ }^{41}$ against 60,000 documents, that is to say, literary papyri account only for $12.8 \%$ of papyrological sources. This is due not only to an extensive bureaucracy that generated many

39 On these phases, see Clarysse/Vandorpe 1995, 24-31.

40 See now in general Houston 2014, which I was, unfortunately, unable to use for this paper.

41 I limit myself to the papyri of Egyptian origin. 
documents, but also to the fact that books, because they were expensive, not as immediately useful as documents, and required owners to have a good level of literacy, could concern only a narrow segment of the population. But the disproportion between libraries and archives is even greater than that between literary and documentary texts ( $4 \%$ versus $12.8 \%$ ). This is due to the insurmountable difficulty of contextualizing literary papyri, that is to say, to put them in connection with other literary texts and with readers or owners. And yet, a library is by definition a group of books stored together at the disposal of one or more individuals. The majority of literary papyri were indeed found illegally, in other words they have no provenance and were scattered (through the networks of antique dealers), while documentary texts that might have accompanied them and thus could have delivered information on their context were separated from them or, conversely, documents of other contexts or provenances were unduly mixed with them. An example is the library (combined with an archive) from Lycopolis and now in the Bibliothèque de l'Institut de France (Paris)..$^{42}$ Among the literary texts of this homogeneous set, there is a fragment of a copy of Aristophanes' comedies which can be joined to three fragments belonging to the Bodleian Library (Oxford $)^{43}$ (Fig. 3). But these were published in 1905 by Grenfell and Hunt who had bought them 'in December 1904 in Cairo, chosen out of a box full of Byzantine papyri from Ashmunen' (ancient Hermopolis). ${ }^{44}$ In fact, the Paris papyri were acquired at about the same time as the Oxford ones (December 1904 and early 1905). It is likely that they were purchased from the same antique dealer, who mixed papyri from various provenance. ${ }^{45}$ This is an example of the difficulties literary papyrologists have to cope with when trying to find the provenance of ancient books.

No internal data make it possible to determine the provenance of a papyrus or its connection with a library: with very few exceptions, books in this periods had no colophon (unlike the Coptic ${ }^{46}$ or Greek medieval books) that could provide

42 See Fournet/Gascou 2008. An edition of these texts (as well as many documentary texts) is being prepared by myself and Jean Gascou.

43 Bodl. Ms. Gr. class. f. 72 (P), edited by Grenfell/Hunt 1905, 212-217.

44 Grenfell/Hunt 1905, 212. For this reason, they were included in the list of literary texts from Hermopolis provided by van Minnen and Worp 1993, 151-186.

45 Fournet/Gascou 2008, 1045-1046.

46 See van Lantschoot 1929. 


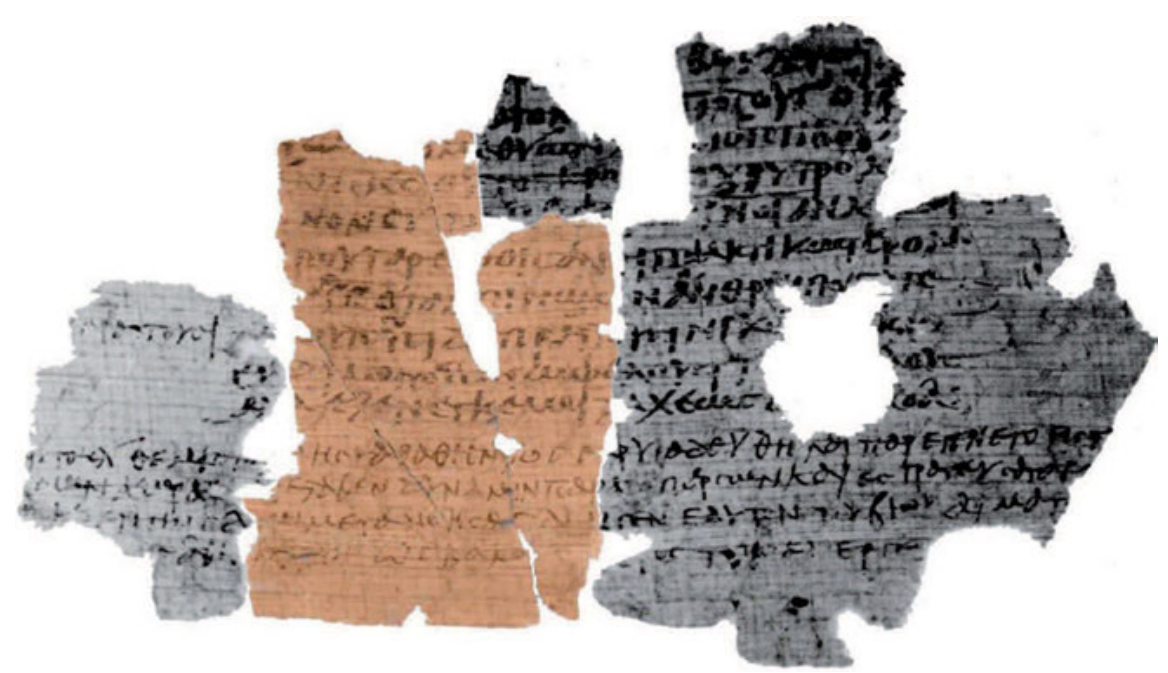

Fig. 3: A sheet from a copy of Aristophanes' Knights: the black-and-white fragments are in Oxford, the colour one in Paris (From CLGP Pars I, vol. 1, fasc. 4, tab. II).

information about the copyist, date and context of the copy; ${ }^{47}$ they had no exlibris or bookplates that would have allowed us to know the owner.

Under these conditions, reconstructing ancient libraries is an almost impossible task. And it is true that it has not aroused the same interest from scholars as the reconstruction of archives. In the past, attention has too often been focused on the famous Library of Alexandria, of which we know little, and only through literary sources, at the expense of the other more real and less fantastic libraries. Moreover, the mass of literary texts found in Egypt has led papyrologists to devote themselves to editing and studying them for their contents and what they can bring to our knowledge of literate practices, neglecting their documentary dimension, their Sitz im Leben. Finally, Egypt has not delivered as spectacular archaeological remains as the great libraries of Asia Minor, Greece and Italy, on which most of the books about libraries of antiquity are based. Elsewhere, we have the

47 There are a few counter-examples: among them are P.Lond.Lit. 11 (first century CE, $\mathrm{MP}^{3}$ 0697, TM 60829), a copy of Iliad to which a kollêma was added with the title and a colophon giving the name of the copyist (Kallinos)-although there is some doubt about the connection of this kollêma with the rest of the roll (see edition); P.Lond.Lit. 97 (second century CE, MP ${ }^{3}$ 2434, TM 63519), a mime with, on the verso, the name of the copyist and of the library where the manuscript used for copying the papyrus was; P.Mil.Vogl. I 19 (MP ${ }^{3}$ 1197; TM 59147), where there may be an allusion to the Roman copyist Sosius (see Turner 1980, 51). 
buildings, but not the texts they contained; in Egypt, we have the texts but rarely the buildings, and yet the texts originating from them are scattered. Therefore, paradoxically, Egypt is the country where the least is known about libraries, despite the fame of the Library of Alexandria.

Libraries in Egypt can be reconstructed from several types of data:

\section{(a) Archaeological data}

Very rare are the libraries that have been found in situ: the most famous is Lucius Calpurnius Piso's library found in his villa at Herculaneum. ${ }^{48}$ But this case is unrelated to Egypt. The other examples are late and from religious contexts:

- The White Monastery library (\# 500) was partially discovered in a small room of the monastery in 1883 by Gaston Maspero. 'Ils y étaient entassés, pêle-mêle sur le sol, “couverts de taches d'eau, de dépôts de terre, de fiente de pigeons ou même d'ordures humaines." ${ }^{49}$ But in fact, the narrowness of the room, for a library that had probably contained more than 2,000 books shows that it was a secondary deposit.

- Smaller are the personal 'libraries' of some monks from the Monastery of Saint Epiphanius, found in their owner's cells. For instance, in Cell A, archaeologists discovered on a mattress fifteen ostraca (sixth-seventh century CE; \# 436) containing biblical and liturgical texts and other texts elsewhere in the same cell. ${ }^{50}$

- Books from ancient libraries have more often been found in dumps, or in contexts which cannot be reconstructed because of excavations which were poorly documented or which ignored stratigraphy. This is the case of most of the papyri from Oxyrhynchus, a city which has delivered the greatest quantity of literary papyri ever found (more than 3,000, or $1 / 3$ of all the literary papyri from Egypt), particularly during the three great 'Literary Finds' (in the winters of 1905-1906), but in excavations carried out according to outdated standards, ignoring the stratigraphic method. By studying the concentration of finds, some collections can be restored. This method was recently applied by George W. Houston, especially for the 'Second Great Find', ${ }^{51}$ which allowed him to reconstitute the profile of the owner of the library and the history of its formation:

\footnotetext{
48 See the introduction to this library recently published by Delattre 2006.

49 See Lefebvre 1920, 500. On this library, see Orlandi 2002; Emmel 2008.

50 Bucking 2007.

51 Houston 2009, esp. table 10.2 and 10.3.
} 
The history of our collection, then, would look something like this: toward the middle of the second century, our collector began to assemble a collection strong in poetry. He may have inherited a preexisting collection, or perhaps he bought a number of rolls (hence the volumes copied in the first century and earlier); he certainly purchased or commissioned a number of new rolls (thus the large number of texts copied in the middle and second half of the second century). The collection so formed reflected its originator's interest in poetry and maintained its shape over time, being added to even when it passed to other owners. At some point toward the middle of the third century, the collection seems to have stopped growing and fallen out of use, and within two or three generations after that the fragments we now have were discarded.52

- Most of the great literary discoveries have been made illegally. This is the case of the 'Bodmer Library' (third-fifth century CE, \# 519), the Gnostic Library of Nag Hammadi (fourth-sixth century CE, \# 496), the Origenian Library of Tura (sixth-seventh CE, \# abest), the Theban Magical Library (third-fourth century CE, \# 363), the Manichean Library of Medinet Madi (third-fourth century CE, \# 497), to name only the most famous. And almost all of them (\# 519, \# 496, \# abest, \# 363) were hidden in caches. We have no archaeological data for them and must resort to other methods.

\section{(b) Data from 'Museum archaeology'}

I have already mentioned this method, but its most spectacular application has been in the case of the 'Bodmer Library', also known as the 'Dishna Papers' (thirdfifth century CE, \# 519), discovered clandestinely in the 1950s. By conducting an inquiry into museums or collections that had acquired papyri at this time and interviewing the persons involved in this discovery, James G. Robinson proposed a reconstruction of the events which led to the papyri being scattered around the world, and, more importantly, established a list of the texts that were part of this library. ${ }^{53}$ Even if some of his conclusions are questionable, I was recently able to confirm the find-site which he had proposed, using a documentary papyrus from the binding of one of the books of this library; this discovery has demonstrated that it came from the region of Dishna, and not Panopolis, as some had thought. ${ }^{54}$

52 Houston 2009, 260-261.

53 Robinson 2011.

54 See Fournet 2015a. 


\section{(c) Codicological and palaeographical data}

The form of literary texts, the type of writing, and the use of diacritics and decorations in their copying can inform us about the milieu of a particular book and, consequently, when scriptoria and libraries are connected, about its possible provenance. ${ }^{55}$ This is how many books have been connected with the library of the White Monastery, or those of the Wadi Natrun monasteries. But much work remains to be done in this area.

\section{(d) Textual data}

Libraries can be known through texts that talk about them. Papyrological sources have transmitted lists of books. Rosa Otranto has identified, in Greek papyri, 19 lists of non-Christian books and six of Christian books. ${ }^{56}$ We must add to them lists in Coptic. ${ }^{57}$ These lists are of various kinds:

- Some tell us about how books circulated and were copied: these are letters in which one asks to borrow books or calls for the return of lent books, or talks about books that have been commissioned. For example, P.Mil.Vogl. I 11 (= Corpus dei Papiri filosofici I.1 * 6), letter from the second century CE:

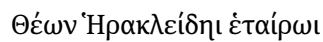

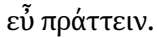

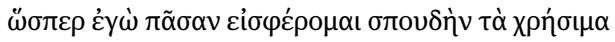

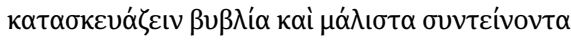

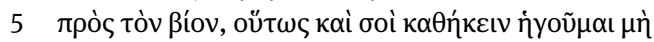

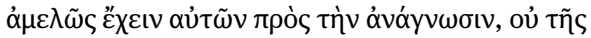

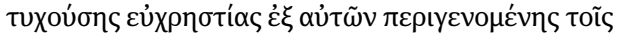

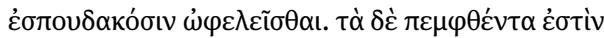

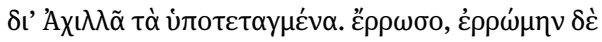

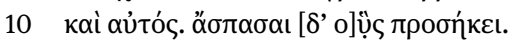

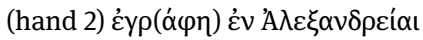

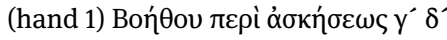

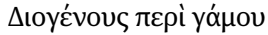

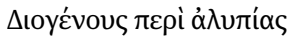

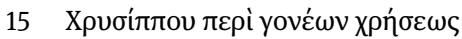

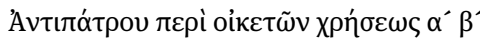

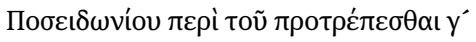

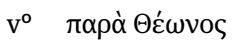

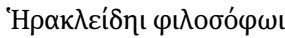

55 See one example with Gascou 2008, 361-363 about the 'Panopolite format.'

56 Otranto 2000.

57 These lists were reviewed by Schmelz 2002, 93-102. Add SB IV 1831, 6-11. 
Theon wishes success to his companion Heracleides.

As I put my zeal in the task to provide you with useful books, and especially those that give meaning to life, I do not think you can overlook their reading given the advantage taken from them by those seeking this benefit. Below is the list of books I am sending via Achillas. Farewell. As for me, I am well. Give my greetings to those to whom it is appropriate.

Written in Alexandria.

Boethus, Exercise, Book III and IV.

Diogenes, Marriage.

Diogenes, Freedom from pain.

Chrysippus, Relationship with parents.

Antipater, Relationship with the house staff, Book I and II.

Posidonius, Exhortation, Book III.

verso

From Theon to Heracleides philosopher.

- Some lists are, however, real inventories (partial or complete) of book collections from a library or institutions (as monasteries or churches) including a library.$^{58}$ One of the finest specimens of inventory is preserved on an ostracon from the library of the Monastery of Saint Elias (SBKopt. I 12, seventh-beginning of the eighth century CE).$^{59}$ For each entry in this 111 line text, it is specified if the book is on papyrus (ХАPTHC) or parchment (ME $<M>$ BPANON), even-

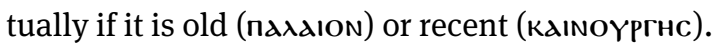

These inventories compensate somewhat for the disappearance of ancient libraries that the sands of Egypt have not preserved, and the scattering of those that were discovered illegally.

\subsection{Typology}

Unlike archives, libraries are never mentioned as such in papyri. The most common term to designate a library, $\beta \iota \beta \lambda_{\llcorner} \theta \eta \dot{\kappa} \kappa$, is used in the documentary sources only for official archives, as we have seen. Yet, it is also the word that designated libraries in Greco-Roman Egypt as evidenced by a note added in red ink on the back of a copy of prose mimes, P.Lond.Lit. 97 (second century CE),${ }^{60}$ which provides not only the name of the copyist, but also that of the library where he got the manuscript he copied:

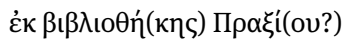

58 Houston 2009, table 10.1.

59 Coquin 1975.

$60 \mathrm{MP}^{3}$ 2434, TM 63519. Last edition: Gammacurta 2006, no. 9. 


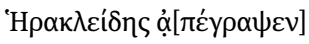

From Praxias’ library. Copied by Heracleides

The typology of libraries is quite similar to that of archives:

\section{(a) Public or institutional libraries}

In this category, we know, strictly speaking, only the famous Great Library attached to the Museum and the Library of the Serapeum, both founded and subsidized by the king. If the first seems to have been reserved for scholars of the Museum, the second might have been open to the public, according to a passage from Aphthonius' Progymnasmata, telling us that it was intended 'to give the whole city an opportunity to philosophize' ${ }^{61}$ These two libraries, widely mentioned in literary sources,${ }^{62}$ have left no trace in documents, ${ }^{63}$ and so I will not dwell on them.

Among institutional libraries, there were those of gymnasia, where young Greeks received sport, military and secondarily cultural training. But we have, for Egypt, no proof of their existence, although it may be inferred from what is known to the rest of the Greek-speaking world. ${ }^{64}$

\section{(b) Private libraries}

These have left more traces in the documentation, and some have even come down to us, as seen before, although not without accidents. While some libraries are general and correspond to the literary tastes of their owner (we saw above that of a lover of poetry in Oxyrhynchus), many others are related to the owner's profession or explained by it. We are fortunate to have some of these specialized libraries: those of two magicians (one from Thebes, third-fourth century CE, \# 363, one from Heracleopolis, fifth-sixth century CE, \# 380); that of an alchemist or magician (Arsinoite, seventh-eighth century CE, \# 435 $5^{65}$ ); perhaps that of a doctor (Lycopolis, fifth century CE, \# 434); that of a rhetorician, Ammon the scholasticus (Panopolite, fourth century CE, \# 31).

61 Prog. 12. According to Canfora 1988, 75-76, Diodorus visited this library during his stay in Egypt. 62 See Calderini 1935, s.v. A` $\lambda \varepsilon \xi \alpha_{\alpha} v \delta \rho \varepsilon เ \alpha, 102$ and 140-141.

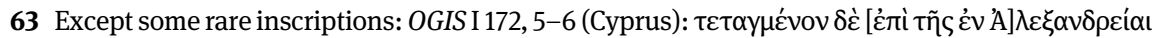

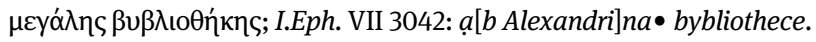

64 See Delorme 1960, 137-140; Maehler 1983, 197.

65 See Dosoo forthcoming. 


\section{(c) Libraries belonging to communities}

These are perhaps best known through spectacular and often clandestine discoveries. Most of them are the libraries of religious communities. With the exception of the library of the Tebtynis temple (fourth century BCE-third century CE), containing books in hieratic and demotic, found in dumps around the temple and scattered among at least eight collections, they are related to Christian monastic establishments: ${ }^{66}$ besides the White Monastery library, mentioned above, we know the Origenian library of the Monastery of Saint Arsene found in Tura (sixth-seventh century CE, \# abest), ${ }^{67}$ the library of the Monastery of Apa Jeremias in Saqqara (fifthsixth century CE, \# 443), and the library composed of the Chester Beatty biblical papyri I-XII, the location of which is still debated (third-fourth century CE, \# abest). Some books may have also belonged to school libraries: it has been suggested that the 'Bodmer library'68 (third-fifth century CE, \# 519), which, alongside Christian books, contained works of secular literature, was a school library; other scholars are inclined to think it was rather the library of a church, a monastery or a sectarian community. It is not, ultimately, impossible that it was a school library in a monastic environment. ${ }^{69}$

The example of the 'Bodmer library' is symptomatic of the difficulties we may encounter when we have to reconstruct the profile of the users of a library of which we no longer know the environment. Attempts have been made to extrapolate from the books it contained, but 'a text, or even a whole library of texts, does not make a sect or a community'. ${ }^{70}$ Is not the very term 'community' improper, in that it implies a homogeneous profile for all the users? Moreover, the 'Bodmer library' developed over three centuries; it is therefore likely to be the aggregate of several collections from various origins that do not necessarily reflect the state of mind of the users at the end of its life. In short, what we lack, in this case, are documents that would tell us more about the context and environment of this library.

But sometimes literary and documentary texts are found in the same collection.

66 The location of the monasteries, installed in the desert, allowed better conservation of texts than churches in urban areas.

67 See Koenen/Müller-Wiener 1968, 41-63 and van Haelst 643 (with bibliography).

68 See van Haelst 7.

69 See Fournet 2015a.

70 Bagnall 1993, 304, on the Nag Hammadi Library. 


\section{Archives and libraries: two sides of the same coin}

So far I have spoken of archives and libraries separately. This separation corresponds to an epistemological cleavage that divides papyrology: on one side, documentary papyrology, on the other literary papyrology. And papyrologists often specialize in one or the other. But this cleavage between documentary collections (archives) and literary collections (libraries) is reductive and unhelpful.

\subsection{Subliterary papyri}

This black and white perception of papyrology does not take into account an intermediate category of texts which makes the link between archives and libraries, between documentary and literary papyrology: subliterary papyri (school texts, magical or medical recipes, etc.). What to do with them? Should we put them on the side of archives (since these are texts that reflect an action in the everyday life) or of libraries (as they result from the study of literature)?

\subsection{An artificial difference}

The difference between archives and libraries that we make today did not have much meaning for the ancients:

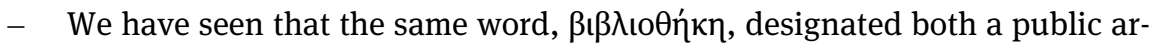
chive and a library.

- As far as individuals are concerned, books and documents were stored in the same place.

- Literary and documentary texts could be written on the same sheet of papyrus, which shows a permeability between these two types of texts. One could reuse a document in order to copy texts of a literary nature in the areas left blank. That is the case of a scroll containing a Coptic settlement that has been transformed into a codex for a handbook of verb conjugation, found in the archive or library of Dioscorus of Aphrodite. ${ }^{71}$ Conversely, literary rolls could

71 P.Aphrod.Lit. III 1, sixth century CE; MP 0355 \& 2161.01, TM 59707. A revised edition of this handbook (taking into account new fragments) is in press (Fournet forthcoming). 
be reused as support for documents, such as a copy of Homer from the archive or library of Epagathos (first century CE; \# 134), the back of which was reused for writing or copying a lease contract, in addition to writing exercises using the text of Homer, in Epagathos' hand. ${ }^{72}$ These secondary uses are not always accidental and can provide interesting information on the profile of those who made them: in the archive of Heroninos, a manager of Appianus' estates (third century CE; \# 103), there was found a letter from Timaios to Heroninos (SB XVIII 13609), written on a sheet cut from a used roll containing the Iliad. ${ }^{73}$ The same Timaios sent another letter to Heroninos, P.Flor. II 259 (249-268), to claim corn he had delayed in shipping to him. He added in the

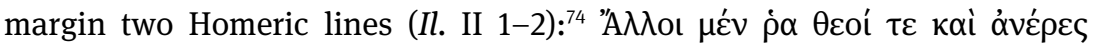

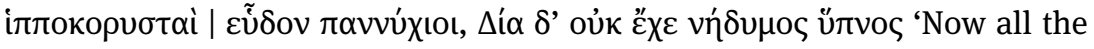
other gods and men, lords of chariots, slumbered the whole night through, but Zeus was not holden of sweet sleep'. These lines are a kind of postscript and are 'ironicamente allusive all'inerzia di Heronino o della gente del suo ufficio'. ${ }^{75}$ 'Possibly the central secretariat [sc. of the administration of Appianus' estate] included one or two scribes who were partly employed as literary copyists, and, when they recopied damaged rolls from Appianus' library, the rolls were then reused for estate correspondence. ${ }^{76}$ Timaios was one of them, which would explain not only his knowledge of Homer, but also the fact that he used old copies of this author to write his letters.

- Finally, books and documents, after mixing on the same shelves, were often stored in the same jar or in the same cache and ended their lives together. The result is a set that combines an archive and a library, what we could call an 'archive-library'. The two most notable examples are the archive-library of the katochoi (recluses) of the Serapeion (Memphis, second century BCE, \# 119) and that of Dioscorus of Aphrodite (Aphrodite, sixth century CE, \# 72).

I have to add a caveat to what I have just said. There is a difference between literary and documentary collections that historians and specialists of literature must take into account: if archives could become quickly outdated and therefore put aside in a jar, or discarded, books could be of interest to future generations, and thus had a longer period of use. Therefore, successors might decide to put away

$72 \mathrm{MP}^{3}$ 0643; TM 60260.

73 The recto contains Il. VIII 30-54 (MP³ 819.1). See Rathbone 1991, 12-13.

$74 \mathrm{MP}^{3}$ 623; TM 60203.

75 Comparetti in the edition.

76 Rathbone 1991, 12. 
documents and keep books for themselves. As a result, libraries found along with the archives only partially reflect the owner's literary interests; they are rather evidence of the disinterest of the person who discarded them. For instance, the jar into which Dioscorus' library was put away contained classical literature (Homer, Menander, Old comedies), but no Christian text, which may seem strange for someone whose father founded the monastery where Dioscorus probably ended his life. This means that these classical texts were not of interest to Dioscorus' heirs (as shown by the fact they employed the codex of Menander as a stopper for the jar!) while they continued to use the Christian texts which they kept.

\subsection{The necessity of establishing links between archives and libraries}

Reconstructing archives or libraries, as we saw in the first two parts, is not enough: we have to combine them as much as possible and cross-check the information given by each of them. Only then will we be able to put books back into the context of their readers and therefore to offer a sociological approach to literature, but also, conversely, to put documents back into the context of their drafters' and readers' literary training. This would lead to the abolition of the cleavage which I have discussed between literature and documents, by trying to identify potential interactions between these two spheres-interactions which became stronger and stronger from the third century onwards. One archive-library demonstrates this particularly well, namely that of Dioscorus of Aphrodite (sixth century CE). ${ }^{77}$

This collection contains not only documents written by Dioscorus and by others, but also poems that he composed ${ }^{78}$ and a part of his own library, including two codices containing Greek comedies (notably of Menander, one of the most important comic poets), ${ }^{79}$ a codex of Homer's Iliad ${ }^{80}$ and another one containing scholia on the Iliad (that is to say a glossary of difficult words or expressions in Homer). ${ }^{81}$ It is the sole papyrological set containing at the same time an original work (Homer), a scholastic book allowing to learn and understand it (the scholia) and literary compositions bearing evidence of its influence on them (the poems). Thus, it sheds light on the three main stages of the Greek learning: schooling,

77 See Fournet 1999 and 2015b.

78 P.Aphrod.Lit. IV (edited in Fournet 1999).

$79 \mathrm{MP}^{3} 1301$ et MP $375=$ TM 61596 (the TM and Cedopal bases do not make the difference between the two codices).

80 P.Aphrod.Lit. I; MP ${ }^{3}$ 658; TM 61072.

81 P.Aphrod.Lit. II; MP³ 1171; TM 61011. 
reading books during one's life and composing literature. The archive-library of Dioscorus shows how those three stages could link to one another.

The archive thus affirms the interaction between literature and documents. The first phenomenon arising from this interaction is one that I have proposed to call the 'literarisation of the document': ${ }^{22}$ quotations from literary works, paraphrases of famous authors, refined expressions, sophisticated terms often derived from poetry began to invade documents. ${ }^{83}$ Even in daily life, one tried to assert one's culture and to use it to one's advantage. The archive-library of Dioscorus exemplifies this phenomenon. Even when he drafts a document, Dioscorus continues to be a poet. This is especially obvious in his petitions. ${ }^{84}$

A reverse, but actually complementary, development also took place: a 'documentarisation' of literature. Literature is also influenced and invaded by documents. The literary corpus opens to documentary genres. Letters and those characteristic artefacts of Late Antiquity, petitions, become, as we have already seen, literary products and sometimes claim a literary status. This phenomenon goes so far that Dioscorus does not hesitate to use poetry for merely documentary purposes. The 'documentarisation' of literature also lies in the fact that the most famous authors, such as Homer or Menander, were given a new function, and obtained a practical role. If Dioscorus had in his library the works of Homer and Menander, it is perhaps because he regarded them as practical handbooks useful to aid in the composition of all sorts of written deeds. This hypothesis is favoured by the number of quotations from these two poets in the documentary production of Dioscorus.

All of these phenomena would not be visible if his library and his archive were not placed in relationship to one another. But this is often hard to do: the first obstacle lies in the nature of literary papyri, which are, as we have seen, difficult to contextualize. But the biggest obstacle could be the epistemological blockage that still separates the world of documents, domain of historians, and the world of books, domain of philologists and specialists of literature. Dialogue between these groups is still too rare, at the expense of a richer and more comprehensive vision of reality. I hope I have made my contribution to this dialogue by promoting the concept of the 'archive-library.'

82 Fournet 2003, 112.

83 On this phenomenon, see recently Fournet 2013.

84 See Fournet 2004, 61-74. 


\section{List of sigla, abbreviations and online resources}

Papyrological publications are abbreviated according to the:

Checklist of Greek, Latin, Demotic and Coptic Papyri, Ostraca and Tablets (http://pa-

pyri.info/docs/checklist).

Otherwise:

$\mathrm{MP}^{3}+$ number $=$ Base de données Mertens $-\mathrm{Pack}^{3}$ (http://promethee.philo.ulg.ac.be/cedopalMP3/indexanglaisMP3.aspx);

Van Haelst + number $=$ van Haelst 1976;

$\mathrm{TM}+$ number = Trismegistos texts database (http://www.trismegistos.org/index2.php);

\# + number = Papyrus Archives in Graeco-Roman Egypt (http://www.trismegistos.org/arch/index.php).

\section{References}

Bagnall, Roger S. (1993), Egypt in Late Antiquity, Princeton: Princeton University Press.

Bagnall, Roger S. (ed.) (2009), The Oxford Handbook of Papyrology, Oxford: Oxford University Press.

Bucking, Scott (2007), 'Scribes and Schoolmasters? On Contextualizing Coptic and Greek Ostraca Excavated at the Monastery of Epiphanius', in Journal of Coptic Studies, 9, 21-47.

Burkhalter, Fabienne (1990), 'Archives locales et archives centrales en Égypte romaine', in Chiron, 20, 191-216.

Calderini, Aristide (1935), Dizionario dei nomi geografici e topografici dell'Egitto grecoromano, I/1, Il Cairo: Società reale di geografia D'Egitto.

Canfora, Luciano (1988), La véritable histoire de la Bibliothèque d'Alexandrie, Paris : Éditions Desjonquères.

Clarysse, Willy (2003), 'Tomoi synkollesimoi', in Maria Brosius (ed.), Ancient Archives and Archival Traditions. Concepts of Record-Keeping in the Ancient World, Oxford: Oxford University Press, 344-359.

Clarysse, Willy, and Katelijn Vandorpe (1995), Zénon, un homme d'affaires grec à l'ombre des Pyramides (Ancorae 14), Louvain: Leuven University Press.

Cockle, Walter E.H. (1984), 'State Archives in Graeco-Roman Egypt from 30 BC to the Reign of Septimius Severus', in Journal of Egyptian Archaeology, 70, 106-122.

Coquin, René-Georges (1975), 'Le catalogue de la bibliothèque du couvent de Saint-Élie “du rocher"', in Bulletin de l'Institut Français d'Archéologie Orientale, 75, 207-239.

Cuvigny, Hélène (ed.) (2006), La route de Myos Hormos. L'armée romaine dans le désert Oriental d'Égypte (Fouilles de l'IFAO, 48), 2nd ed., Le Caire : Institut français d'archéologie orientale.

Cuvigny, Hélène (2009), 'The Finds of the Papyri: The Archaeology of Papyrology', in Roger S. Bagnall (ed.), The Oxford Handbook of Papyrology, Oxford: Oxford University Press, 30-58.

Delattre, Daniel (2006), La Villa des Papyrus et les rouleaux d'Herculanum. La Bibliothèque de Philodème (Cahiers du CEDOPAL 4), Liège : CEDOPAL et Les Editions de l'Université de Liège. 
Delorme, Jean (1960), Gymnasion. Études sur les monuments consacrés à l'éducation en Grèce (des origines à l'Empire romain), Paris : Éd. E. de Boccard.

Dosoo, Korshi (forthcoming), 'Horus, Sabaoth, Satanas: La "Bibliothèque de Berlin" et autres fonds d'archives magiques dans l'Égypte romaine et les premiers siècles de la période islamique', in Jean-Charles Coulon (ed.), La magie et les sciences occultes dans le monde islamique, Paris.

Emmel, Stephen (2008), 'The Library of the White Monastery in Upper Egypt', in Harald Froschauer and Cornelia Römer (eds), Spätantike Bibliotheken. Leben und Lesen in den frühen Klöstern Ägyptens (Nilus 14), Vienna: Phoibos-Verlag, 5-14.

Fournet, Jean-Luc (1999), Hellénisme dans l'Égypte du VI siècle. La bibliothèque et l'œuvre de Dioscore d'Aphrodité, 2 vols (Mémoires de l'Institut français d'archéologie orientale 115/1-2), Cairo: Institut français d'archéologie orientale.

Fournet, Jean-Luc (2003), 'Between Literary Tradition and Cultural Change. The Poetic and Documentary Production of Dioscorus of Aphrodite', in Alasdair A. MacDonald, Michael W. Twomey and Gerrit J. Reinink (eds), Learned Antiquity. Scholarship and Society in the NearEast, the Greco-Roman World, and the Early Medieval West, Leuven: Peeters, 101-114.

Fournet, Jean-Luc (2004), 'Entre document et littérature : la pétition dans l’Antiquité tardive', in Denis Feissel and Jean Gascou (eds), La pétition à Byzance (Centre de recherche d'Histoire et Civilisation de Byzance, Monographie, 14), Paris: Association des amis du Centre d'histoire et civilisation de Byzance, 61-74.

Fournet, Jean-Luc (2013), 'Culture grecque et document dans l'Égypte de l'Antiquité tardive', in Journal of Juristic Papyrology, 43, 135-162.

Fournet, Jean-Luc (2015a), 'Anatomie d'une bibliothèque de l'Antiquité tardive', in Adamantius, $21,8-40$.

Fournet, Jean-Luc (2015b), 'At the Desk of a Man of Letters: Literate Practices in Byzantine Egypt according to the Dossier of Dioscorus of Aphrodite', in Scott F. Johnson (ed.), Languages and Cultures of Eastern Christianity: Greek (The Worlds of Eastern Christianity, 300-1500, 6), Farnham: Ashgate, 221-248.

Fournet, Jean-Luc (forthcoming), Apprendre à conjuguer dans l'Égypte byzantine : un manuel de conjugaison grecque de la bibliothèque de Dioscore d'Aphrodité (Papyrologica Bruxellensia), Bruxelles.

Fournet, Jean-Luc, and Jean Gascou (2008), 'Un lot d'archives inédit de Lycopolis (Égypte) à l'Académie des Inscriptions et Belles-Lettres', in Comptes rendus des séances. Académie des Inscriptions \& Belles-Lettres, 1041-1074.

Franz, Eckhart G. (1993), Einführung in die Archivkunde, 4th ed., Darmstadt: Wissenschaftliche Buchgesellschaft.

Gallazzi, Claudio (1989), 'Fouilles anciennes et nouvelles sur le site di Tebtynis', in Bulletin de l'Institut Français d'Archéologie Orientale, 89, 180-202.

Gallazzi, Claudio (1990), 'La “Cantina dei Papiri” di Tebtynis e ciò che essa conteneva', in Zeitschrift für Papyrologie und Epigraphik, 80, 283-288.

Gammacurta, Tatiana (2006), Papyrologica scaenica, Alessandria: Edizioni dell'Orso.

Gascou, Jean (2008), Fiscalité et société en Égypte byzantine (Bilans de Recherche, 4), Paris: Association des amis du Centre d'histoire et civilisation de Byzance.

Grenfell, Bernard P., and Arthur S. Hunt (1905), 'Some Classical Fragments from Hermopolis', in Mélanges Nicole, I, Genève: W. Kündig, 212-217.

Hickey, Todd M. (2012), Wine, Wealth, and the State in Late Antique Egypt: The House of Apion at Oxyrhynchus, Ann Arbor: University of Michigan Press. 
Houston, George W. (2009), 'Papyrological Evidence for Book Collections and Libraries in the Roman Empire', in William A. Johnson and Holt N. Parker (eds), Ancient Literacies: The Culture of Reading in Greece and Rome, Oxford: Oxford University Press, 233-267.

Houston, George W. (2014), Inside Roman Libraries: Book Collections and Their Management in Antiquity, Chapel Hill: University of North Carolina Press.

Jördens, Andrea (2001), 'Papyri und private Archive. Ein Diskussionsbeitrag zur papyrologischen Terminologie', in Eva Cantarella and Gerhard Tür (eds), Symposion 1997: Vorträge zur griechischen und hellenistischen Rechtsgeschichte (Altafiumara, 8.-14. Sept. 1997) (Akten der Gesellschaft für griechische und hellenistische Rechtgeschichte, 13), Cologne: Böhlau, 253-267.

Koenen, Ludwig, and Wolfgang Müller-Wiener (1968), 'Zu den Papyri aus dem Arsenioskloster bei Tura', in Zeitschrift für Papyrologie und Epigraphik, 2, 41-63.

Lefebvre, Gustave (1920), 'Deir-el-Abiad', in Fernand Cabrol and Henri Leclercq (eds), Dictionnaire d'archéologie chrétienne et de liturgie, IV: D-Domestici, Paris: Letouzey et Ané, 459-502.

Maehler, Herwig (1983), 'Die griechische Schule im ptolemäischen Ägypten', in Edmond van’t Dack, Peter van Dessel and Wilfried van Gucht (eds), Egypt and the Hellenistic World (Studia Hellenistica 27), Leuven : Peeters, 191-203; repr. in Csaba Láda and Cornelia Römer (eds), Schrift, Text und Bild. Kleine Schriften von Herwig Maehler (Archiv für Papyrusforschung und verwandte Gebiete. Beiheft 21), Munich, Leipzig: K.G. Saur 2006, 187-196.

Martin, Alain (1994), 'Archives privées et cachettes documentaires', in Adam Bülow-Jacobsen (ed.), Proceedings of the 20th International Congress of Papyrologists. Copenhagen, 2329 August 1992), Copenhagen: Museum Tusculanum Press, 569-577.

Mazza, Roberta (2001), L'archivio degli Apioni. Terra, lavoro e proprietà senatoria nell'Egitto tardoantico, Bari: Edipuglia.

McGing, Brian C. (1990), 'Melitian Monks at Labla', in Tyche, 5, 67-94.

Mélèze-Modrzejewski, Joseph (1979), 'Chronique. Droits de l’Antiquité. Égypte gréco-romaine et monde hellénistique', in Revue historique de droit français et étranger, 57, 120-147.

Mélèze-Modrzejewski, Joseph (1989), 'Chronique. Droits de l’Antiquité. Égypte gréco-romaine et monde hellénistique', in Revue historique de droit français et étranger, 67, 505-568.

Montevecchi, Orsolina (1988), La papirologia, 2nd ed., Milano: Vita e pensiero.

Orlandi, Tito (2002), 'The Library of the Monastery of Saint Shenute at Atripe', in Arnold Egberts, Brian P. Muhs and Jacques Van der Vliet (eds), Perspectives on Panopolis: An Egyptian Town from Alexander the Great to the Arab Conquest (Papyrologica Lugduno-Batava, 31), Leiden: Brill, 211-231.

Orrieux, Claude (1985), Zénon de Caunos, parépidèmos, et le destin grec, Besançon, Paris: Les Belles Lettres.

Otranto, Rosa (2000), Antiche liste di libri su papiro (Sussidi eruditi 49), Rome: Ed. di Storia e Letteratura.

Pestman, Pieter W. (ed.) (1989), Familiearchieven uit het land van Pharao, Zutphen: Uitgeverij Terra (non vidi).

Pestman, Pieter W., with contributions by Willy Clarysse, Monika Korver, Michel Muszynski, Annette L. Schutgens, William John Tait and Jan Krzystof Winnicki (1981), A Guide to the Zenon Archive. Lists and Surveys; Indexes and Maps (Papyrologica Lugduno-Batava 21AB), Leiden: Brill.

Pestman, Pieter W. (1990), New Papyrological Primer, Leiden: Brill. 
Rathbone, Dominic (1991), Economic Rationalism and Rural Society in Third-Century A.D. Egypt. The Heroninos Archive and the Appianus Estate, Cambridge: Cambridge University Press.

Robinson, James M. (2011), The Story of the Bodmer Papyri. From the First Monastery's Library in Upper Egypt to Geneva and Dublin, Eugene, OR: Cascade Books.

Schmelz, Georg (2002), Kirchliche Amtsträger im spätantiken Ägypten nach den Aussagen der griechischen und koptischen Papyri und Ostraka (Archiv für Papyrusforschung und verwandte Gebiete. Beiheft 13), Munich: K.G. Saur, 93-102.

Turner, Eric G. (1980), Greek Papyri. An Introduction, 2nd ed., Oxford: Clarendon.

Van Beek, Bart (2007), 'Ancient Archives and Modern Collections: The Leuven Homepage of Papyrus Archives and Collections', in Jaakko Frösén, Tiina Purola and Erja Salmenkivi (eds), Proceedings of the XXIVth International Congress of Papyrology. Helsinki, 1-7 August 2004 (Commentationes humanarum litterarum 122), Helsinki: Societas scientiarum Fennica, 1033-1044.

van Haelst, Joseph (1976), Catalogue des papyrus littéraires juifs et chrétiens (Série ‘Papyrologie' 1), Paris: Publications de la Sorbonne.

van Lantschoot, Arnold (1929), Recueil des colophons des manuscrits chrétiens d'Égypte, I: Les colophons coptes des manuscrits sahidiques (Bibliothèque du Muséon, 1), Louvain: J.-B. Istas.

van Minnen, Peter, and Klaas A. Worp (1993), 'The Greek and Latin Literary Texts from Hermopolis', in Greek, Roman and Byzantine Studies, 34, 151-186.

van Minnen, Peter (1994), 'House-to-House Enquiries: An Interdisciplinary Approach to Roman Karanis', in Zeitschrift für Papyrologie und Epigraphik, 100, 227-251.

Vandorpe, Katelijn (1994), 'Museum Archaeology or How to Reconstruct Pathyris Archives', in Egitto e Vicino Oriente, 17 (= Acta Demotica. Acts of the Fifth International Conference for Demotists. Pisa, 4th-8th September 1993), 289-300.

Vandorpe, Katelijn (2009), 'Archives and Dossiers', in Roger S. Bagnall (ed.), The Oxford Handbook of Papyrology, Oxford: Oxford University Press, 216-255.

Vogliano, Achille (1938), 'Un rapporto preliminare della IVa campagna di scavo a Medinet Madi', in Annales du Service des Antiquités de l'Égypte, 38, 533-549.

Yadin, Yigael (1962), 'The Cave of the Letters', in Israel Exploration Journal, 12, 227-257. 